\title{
Economic and ecological values of frass fertiliser from black soldier fly agro-industrial waste processing
}

\author{
D. Beesigamukama ${ }^{1,2,3^{*}}$, B. Mochoge ${ }^{2}$, N. Korir ${ }^{2}$, K. Menale ${ }^{1}$, B. Muriithi ${ }^{1}$, M. Kidoido ${ }^{1}$, H. Kirscht ${ }^{1}$, G. Diiro ${ }^{1}$, \\ C.J. Ghemoh ${ }^{5}$, S. Sevgan ${ }^{1}$, D. Nakimbugwe ${ }^{4}$, M.W. Musyoka ${ }^{1}$, S. Ekesi ${ }^{1}$ and C.M. Tanga $^{1^{*}}$ iD \\ ${ }^{1}$ International Centre of Insect Physiology and Ecology, P.O. Box 30772-00100, Nairobi, Kenya; ${ }^{2}$ Department of Agricultural \\ Science and Technology, Kenyatta University, P.O. Box 43844-00100, Nairobi, Kenya; ${ }^{3}$ Department of Crop Production \\ and Management, Busitema University, P.O. Box 236, Tororo, Uganda; ${ }^{4}$ Department of Food Technology and Nutrition, \\ School of Food Technology, Nutrition E Bioengineering, Makerere University, P.O. Box 7062, Kampala, Uganda; ${ }^{5}$ Centre \\ for African Bio-Entrepreneurship (CABE), P.O. Box 25535-00603, Lavington, Nairobi, Kenya; dbeesigamukama@icipe.org; \\ dbesiga@gmail.com; ctanga@icipe.org
}

Received: 26 January 2021 / Accepted: 8 July 2021

(c) 2021 Wageningen Academic Publishers

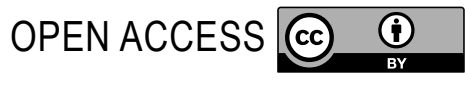

RESEARCH ARTICLE

\begin{abstract}
The sustainable utilisation of black soldier fly (BSF) for recycling organic waste into high-quality protein feed and organic fertiliser with a low environmental footprint is gaining momentum worldwide. Although BSF farming is becoming a rapidly growing agribusiness, studies on the BSF farming's economic aspects are limited. This study analysed the economic benefits of farming BSF for animal feeds and composted frass, called frass fertiliser (FF) production using experimental data. The BSF larvae were fed on brewery spent grain amended with sawdust, biochar, and gypsum to determine the cost-effective feed and other by-products production. The agronomic performance of FF on the maize crop was assessed using field experiments. Our results demonstrated that sourcing and preparing the waste substrate for rearing the BSF larvae accounts for $81-90 \%$ of the total BSF production cost. The utilisation of FF as an additional value-added product would increase farmer's net income by 5-15 folds compared to BSF farming alone. Feedstock amended with 20\% biochar increased net income by 10-64\% for BSF larvae and FF production than other feedstocks. Production of one megagram (Mg) of dried BSF larvae (USD 900) would generate 10-34 Mg of FF worth USD 3,000-10,200. Maize grown on plots treated with FF yielded 29-44\% higher net income than maize harvested from plots amended with commercial organic fertiliser. Furthermore, smallholder insect farmers' direct use of FF for maize production would generate $30-232 \%$ higher net income than farmers purchasing similar FF. Our results demonstrate for the first time the role of insect farming in circular economy and justify the opportunities for future investments that would lead to enhanced sustainability for agricultural and food systems, especially for smallholder farmers in low- and middle-income countries.
\end{abstract}

Keywords: black soldier fly farming, frass fertiliser, maize production, profitability, circular economy

\section{Introduction}

Poor soil health and feed scarcity are among major challenges affecting the food and nutrition security of subSaharan Africa (SSA) (Alltech, 2016; Ssepuuya et al., 2017; Tully et al., 2015). Most soils (40\%) in SSA are nutrient deficient (Cobo et al., 2010; Tully et al., 2015), and yet, very little ( $\leq 10 \mathrm{~kg} / \mathrm{ha} /$ year) or no mineral fertiliser is used due to high prices and limited access (FAO, 2017; Stewart et $a l ., 2020)$. Even in the few farms where mineral fertilisers are used, low agronomic use efficiencies and crop yields have been reported (Kihara et al., 2016; Liverpool-Tasie et al., 2017), mostly attributed to low soil organic matter levels, secondary and micronutrient deficiencies, and high acidity (Vanlauwe et al., 2015; Wortmann et al., 2019). Previous research efforts on soil fertility management in SSA (Stewart et al., 2020; Tittonell et al., 2008; Vanlauwe et al., 2014, 2015) have recommended the combined 
application of mineral and organic fertilisers to improve and sustain soil health and crop yields. However, the use of organic fertilisers is greatly hindered by the limited source of organic matter since most organic resources have other competing uses, such as feeding livestock on the farm (Ndambi et al., 2019; Rufino et al., 2011). In addition to the low crop productivity, animal (fish, poultry, and piggery) production in SSA is also constrained by feed scarcity since the conventional protein sources such as fish and soy meal have become scarce and more expensive (Ssepuuya et al., 2017).

Insects have been recommended as as alternative sources of animal feeds and efficient recyclers of organic waste into quality organic fertiliser (Beesigamukama et al., 2021; Makkar et al., 2014; Van Huis, 2013). Insects as feed and food are increasingly gaining momentum due to the high cost of conventional feed sources, high demand for animal protein, and concerns related to climate change impact caused by conventional feed sources and animal products (Dobermann et al., 2017; Mertenat et al., 2019; Van Huis and Oonincx, 2017). Recent estimates have put the global feed market demand at 464, 254, 35, and 23 million megagrams (Mg) for poultry, pigs, cultured fish, and pets, respectively (Alltech, 2016). Therefore, the use of insect-based feeds is expected to contribute immensely to the global feed supply while mitigating adverse environmental effects (Dobermann et al., 2017; Makkar et al., 2014).

The black soldier fly (BSF) (Hermetia illucens L.) is a widely distributed insect in the tropics with high nutritional value and waste conversion efficiency (Dobermann et al., 2017). The dry BSF larvae contain about $42-49 \%$ crude proteins, $38 \%$ lipids, $20 \%$ crude fiber, $20 \%$ ash, and vitamins (Makkar et al., 2014), which have been shown to improve poultry (Kierończyk et al., 2020; Schiavone et al., 2017; Sypniewski et al., 2020), pig, and fish (Kroeckel et al., 2012;
Magalhães et al., 2017) production. In Kenya, the potential macroeconomic impact of adopting BSF larval meals in the poultry sector has been estimated at 16-687 million USD per year (Abro et al., 2020), not forgetting other benefits such as job creation along the value chain and the value of environmental sanitisation.

Recent studies show BSF's technical and potential economic feasibility (Abro et al., 2020; Chia et al., 2019), however, insect production still faces many hurdles, including selecting an effective rearing substrate (Dobermann et al., 2017; Makkar et al., 2014; Van Huis, 2013). The required quantities of organic wastes to rear BSF may not be readily available on the farm for mass production. This implies that insect farmers would incur costs to either purchase or transport rearing substrates or both. Our preliminary assessments have shown that, the rearing substrate alone accounts for the highest share of overhead costs during BSF rearing. Such costs may not be covered only by revenues generated from sales of insect larvae. The second source of revenue from sales or use of the utilised rearing substrates may also be required.

Combining BSF protein with organic fertiliser production could make BSF rearing more profitable (Figure 1). Moreover, recent studies have reported increased growth and yield of crops grown using BSF frass fertiliser (Beesigamukama et al., 2020a; Bortolini et al., 2020; Choi and Hassanzadeh, 2019; Quilliam et al., 2020). The BSF frass fertiliser is a by-product that is gaining popularity due to its high nutrient content and potential for use as organic fertiliser (Anyega et al., 2021; Bortolini et al., 2020; Gärttling et al., 2020; Lalander et al., 2015; Oonincx et al., 2015; Setti et al., 2019). Generating frass fertiliser from BSF farming would create a valuable product for farmers already producing BSF larvae for animal feeding purposes.

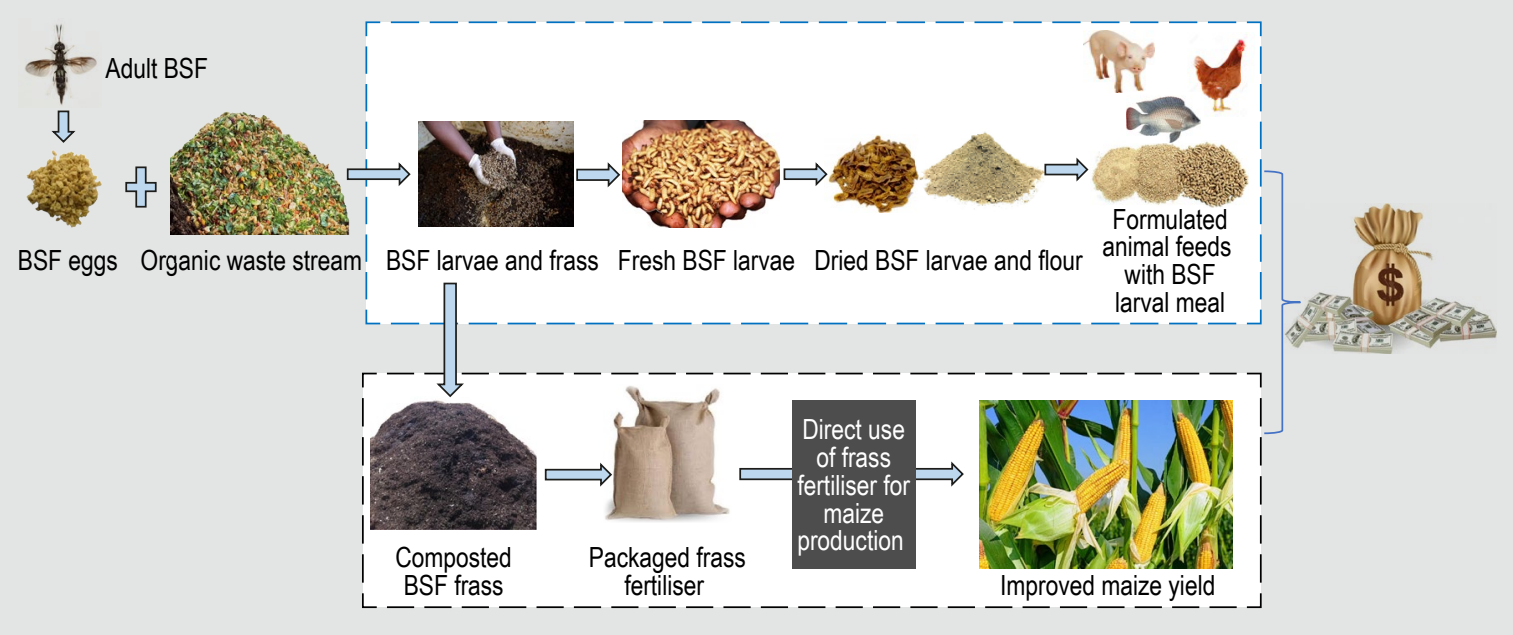

Figure 1. Schematic diagram of black soldier fly (BSF) circular economy production system. 
Although some studies show the nutritional profile of BSF larvae and the technical feasibility of BSF farming, there is still limited research that shows the economic benefits of frass fertiliser. Abro et al. (2020), using a replacement cost approach, estimated the macroeconomic gains of BSF frass at 9-85 million USD in Kenya. However, their estimate did not consider the cost of producing frass fertiliser and the direct economic benefits that can be achieved while using frass fertiliser for crop production. This paper addresses this gap by estimating the economic value of producing frass fertiliser as a new value-added product of BSF farming for maize production. We further assess the optimum frass fertiliser required for maximum maize production.

\section{Materials and methods}

\section{Economic value of frass fertiliser as a by-product of black soldier fly farming}

We used gross margins, benefit-cost ratio, and return on investment to assess frass fertilisers' technical and economic efficiency. These were computed as follow (Chia et al., 2019):

$$
\begin{aligned}
& \text { Gross margin }(\%)=\frac{\text { Net income }}{\text { Gross income }} \times 100 \\
& \text { Benefit }- \text { cost ratio }=\frac{\text { Net income }}{\text { Total variable costs }} \\
& \text { Return on investment }(\%)=\frac{\text { Net income }}{\text { Total variable costs }} \times 100
\end{aligned}
$$

where Net income $=$ Gross income - Total variable costs.

The economic analysis was computed under two options: (1) BSF farming solely for larvae production; and (2) BSF farming for larvae and frass fertiliser production. Under the first option, the BSF production process ended at the $5^{\text {th }}$ instar larval stage, when the larvae are usually harvested and processed for animal feeding purpose. The variable costs of insect production included rearing substrates transport, water, electricity, and labor for egg collection, feeding, and harvesting and drying the BSF larvae. Labor costs were calculated using a wage rate of 1.25 USD per hour (Kenya Government, 2019).

Under the second option, after larvae harvesting, frass was collected and composted to convert it into an organic fertiliser referred to as frass fertiliser, following the procedures described in Beesigamukama et al. (2020b). The additional costs incurred, such as transporting frass to the composting site and managing the frass to convert it into organic fertiliser, were added to the fertiliser production costs. The quantity of dry frass fertiliser and dry BSF larvae was obtained from each waste combination to measure the gross income.
The BSF larvae were reared in metallic trays using brewery spent grain (BSG) feedstock described by Shumo et al. (2019). BSG was chosen as the primary rearing substrate due to its high suitability for BSF larval performance (Chia et al., 2018; Shumo et al., 2019) and availability in large quantities. The BSG (one Mg dry weight) was amended with different quantities of sawdust (0, 9, 20,32, and 44\%), biochar $(0,5,10,15$, and $20 \%)$, and gypsum $(0,5,10$, and $15 \%)$ to develop a substrate formulation that could conserve enough nutrients for cost-effective production of high BSF larval biomass and frass fertiliser (Beesigamukama et al., 2020c, 2021; Huang et al., 2004; Li et al., 2018). The costs of substrate amendments (sawdust, biochar, and gypsum) were included as a part of production costs under the second option. After 14 days of rearing ( $5^{\text {th }}$ instar stage), the BSF larvae were harvested, and the quantity of dry larvae obtained per treatment was recorded.

The performance of BSF larvae on BSG was comparable with those of other wastes such as chicken manure and kitchen waste (Shumo et al., 2019) that can be readily available both on- and off-farm. We, therefore, considered two scenarios of rearing substrate in establishing the technical and economic benefits of frass fertiliser: (1) BSF farming when the main rearing substrate is purchased and transported to the farm; and (2) BSF farming when the main rearing substrate is available on the farm, i.e. no substrate acquisition costs (purchase or transport) incurred.

\section{Impact of black soldier fly frass fertiliser on maize production}

We conducted on-station field experiments for two seasons (April - September 2019 and October 2019 - March 2020) to determine the economic return to using organic fertiliser for maize production. We used gross margins, benefit-cost ratio, and return on investment as described in Equations 1 to 3. We compared the economic return to organic fertiliser from insect farming with mineral fertiliser (urea) and commercial organic fertiliser.

Price data for fertilisers and maize seed (variety H513) were obtained from Africa fertiliser and Kenya farmers' association (Africa Fertilizer, 2019). We estimated labor expenses (land preparation, planting, weeding, fertiliser application, and harvesting) by recording the time taken to perform each activity and valuing labor at the rate of 1.25 USD per hour (Kenya Government, 2019). Maize grain and stover yields were considered in the economic impact analysis of organic fertiliser for maize production. The price of maize grain was obtained from human data exchange (Humanitarian Data Exchange, 2020). Since stover is used as an animal feed in Kenya, it was considered an additional output and valued at 22.1 USD per Mg (Mucheru-Muna et al., 2014). 
The field tests consisted of the BSF frass fertiliser, commercial organic fertiliser (SAFI), and mineral nitrogen (N) fertiliser (46\% $\mathrm{N}$ urea) each applied at three rates equivalent to 30, 60, and $100 \mathrm{~kg} \mathrm{~N} / \mathrm{ha}$. These experiments aimed to determine the optimum fertiliser application rates for maize production. The experiments were conducted on fields of $4 \times 4 \mathrm{~m}$ in a randomised complete block design with three replicates per treatment. They were managed according to the recommended agronomic procedures up to maturity (Beesigamukama et al., 2020a). Grain yield data were collected at the harvesting stage from each plot after all the ears had dried. Plants in the harvested area were cut at ground level, and their ears threshed to determine grain and residues' weights using a weighing scale. Grain and stover samples were taken to the laboratory and air-dried to $12.5 \%$ moisture content to determine grain and residues yields per plot and calculated on a hectare basis ( $\mathrm{kg} / \mathrm{ha})$.

\section{Economically optimum frass fertiliser rates for maize production}

The maize grain yields were regressed as a function of fertiliser rates, and the response curve was drawn for each fertiliser treatment. The use of a quadratic function to determine optimum fertiliser rates is common in literature (Naher et al., 2011).

$Y=a+b N+c N^{2}$

Equation 4 used to determine the optimum nitrogen $(\mathrm{N})$ fertiliser rate as:

$N=\frac{E_{n}-b}{2 c}$

where,

$Y$ is maize grain yield in $\mathrm{kg}$ per hectare

$N$ is the rate of nitrogen fertiliser $(\mathrm{kg} / \mathrm{ha})$

$a, b$, and $c$ are parameters to be estimated

$E_{n}$ represents the ratio of fertiliser price $\left(P_{f}\right)$ to maize price $\left(\mathrm{P}_{\mathrm{y}}\right), E_{n}=P_{f} / P_{y}$

$P_{f}$ represents the price of fertiliser (urea, frass fertiliser, and SAFI organic) per $\mathrm{kg}$

$P_{y}$ represents the price of maize per $\mathrm{kg}$

\section{Results and discussion}

\section{Economic returns of frass fertiliser to black soldier fly farming}

The yields of BSF larva and frass fertiliser and economic return from two BSF farming scenarios are presented in Tables 1 and 2. The rearing substrate cost accounted for the most expenses of BSF farming (81-90\%) (Table 1 and 2 ), while costs incurred on substrates amended by sawdust were minimal. This study has demonstrated that a farmer who incurs costs of purchasing and transporting the rearing substrates for larval production only would be operating at a loss indicated by the negative net income values (Table 1 and 2). This is further confirmed by the negative values of return on investment, benefit-cost ratio and gross margin (Figure 2).

The combination of BSF larvae and frass fertiliser considerably increases the income from insect framing. This study has established that for every $\mathrm{kg}$ of BSF larvae produced, 10-17, 10-19, 19-34, and 12-15 kg of frass fertiliser are generated using the unamended substrate, substrates amended with sawdust (Table 1), gypsum, and biochar (Table 2), respectively. However, even with organic fertiliser production, BSF farming is still nonprofitable if the BSF farmer incurs costs on the rearing substrate (Table 1 and 2). Contrarily, amending the substrate with $20 \%$ sawdust and producing organic fertiliser from the frass can generate positive profit even if the BSF farmer incurs costs on the rearing substrate. Therefore, any strategy for improving the profitability of BSF farming should consider the rearing substrate's availability at a low or affordable cost.

The net income was positive when the rearing substrate's cost was excluded, that is, when the substrate is available on the farm (Table 1 and 2). However, this was only achieved in production systems where both larvae and frass fertiliser production are considered, indicating that frass fertiliser is crucial for improving BSF farming's cost-effectiveness. This study estimated that the production of $1 \mathrm{Mg}$ of dried BSF larvae (USD 900) would generate 10-34 Mg of frass fertiliser worth USD 3,000-10,200. Results indicate that net income increased by 11-15, 4.8-4.9, and 5-6 times for substrates amended with sawdust (Table 1), gypsum, and biochar (Table 2), respectively, compared to rearing BSF for larvae production alone. For example, amending the rearing substrate with $20 \%$ sawdust increased the net income from BSF larvae and frass fertiliser by $33 \%$ compared to the unamended substrate (Table 1). Simialrly, amending the rearing substrate with gypsum and biochar increased the net income from BSF larvae and frass fertiliser by $5-8$ and $3-28 \%$, respectively, compared to the unamended substrate (Table 2). The higher net income achieved from substrates amended with 15 and $20 \%$ biochar can be attributed to the positive impact of biochar on both larval and frass fertiliser yields. Biochar is a bulking agent, and its amendment improves nutrient and moisture retention and porosity of organic substrates, which are favorable for BSF larval growth and yield (Sanchez-Monedero et al., 2018).

The high gross margin and return on investment (Figure 2) obtained using unamended substrate indicate that generating organic fertiliser as a second high valuable product from BSF farming has a high potential to benefit farm households which are liquidity constrained to purchase ingredients to amend substrates. However, since the net income generated using an amended substrate with either 


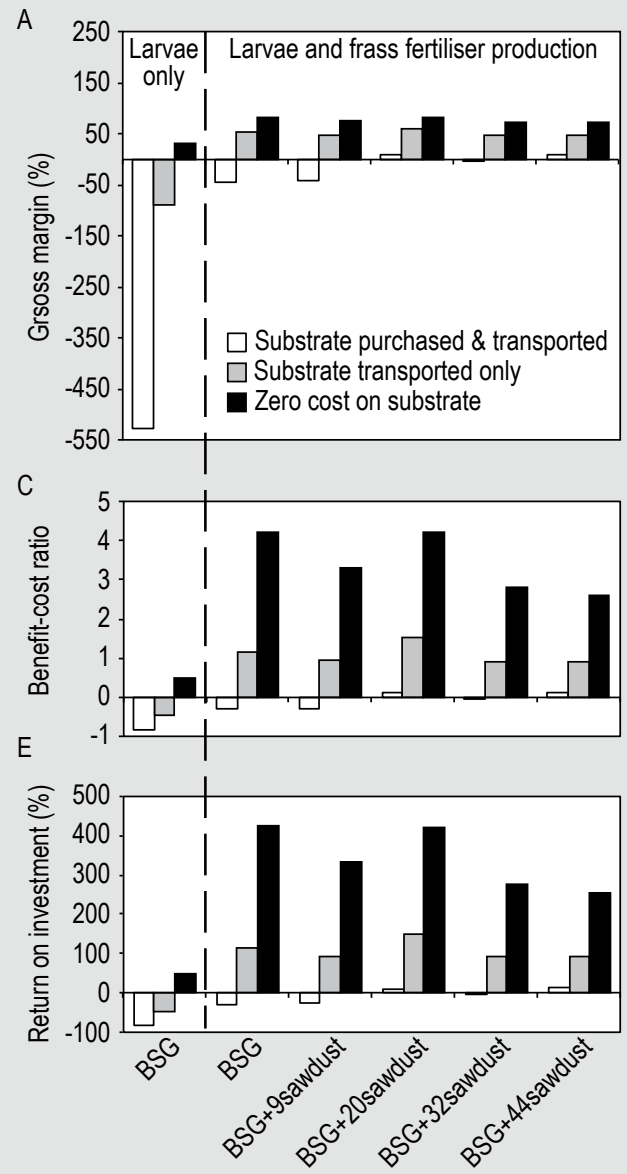

Rearing substrates
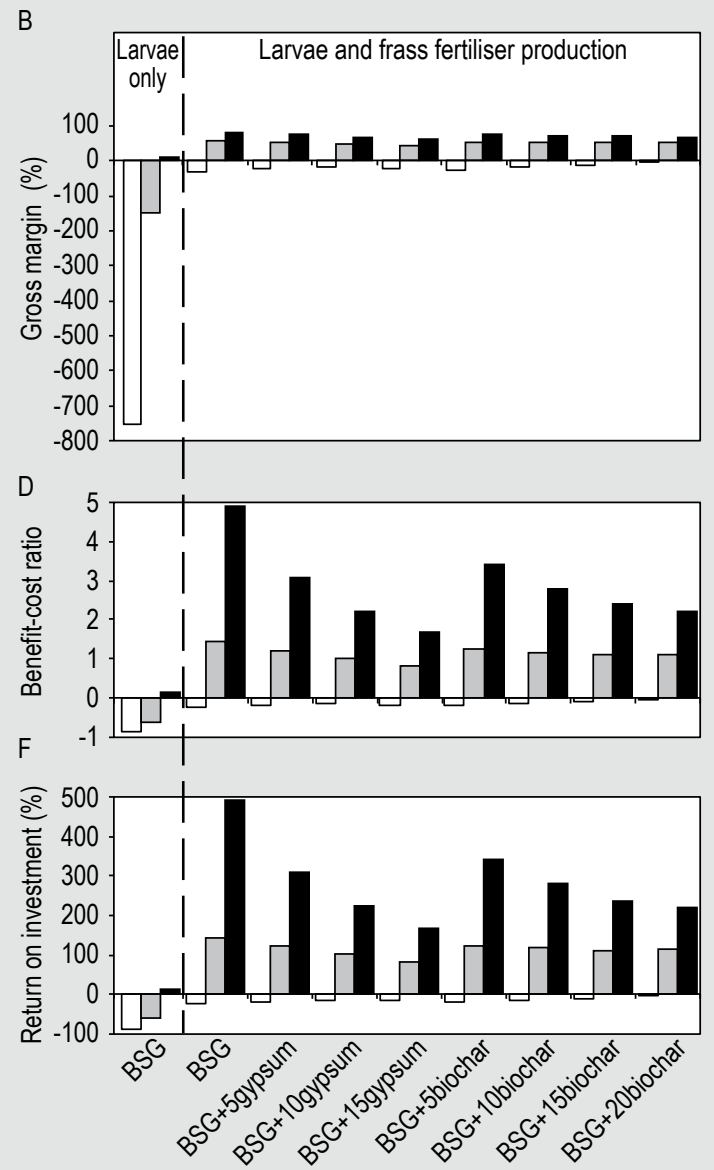

Rearing substrates

Figure 2. Gross margin ( $A$ and $B)$, benefit-cost ratio $(C$ and $D)$, and return on investments ( $E$ and $F$ ) from two black soldier fly farming scenarios using rearing substrates amended with sawdust $(A, B$ and $C)$, biochar and gypsum $(B, D$ and $F)$. BSG = brewery spent grain.

Table 1. Economic returns from black soldier fly (BSF) production using sawdust amended rearing substrates. ${ }^{1}$

\begin{tabular}{|c|c|c|c|c|c|c|c|c|c|}
\hline \multirow[b]{2}{*}{ Rearing substrates } & \multirow[b]{2}{*}{ 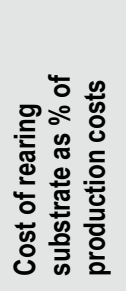 } & \multirow[b]{2}{*}{ 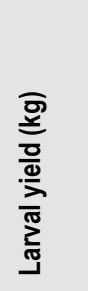 } & \multirow{2}{*}{ 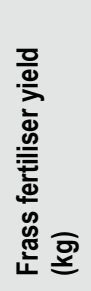 } & \multirow[b]{2}{*}{ 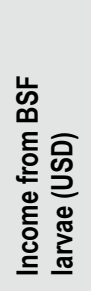 } & \multirow{2}{*}{ 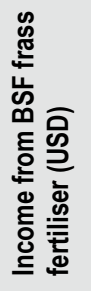 } & \multirow{2}{*}{ 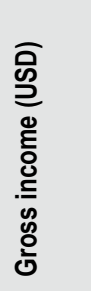 } & \multirow{2}{*}{ 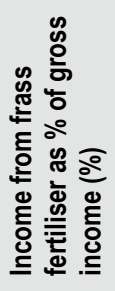 } & \multicolumn{2}{|c|}{$\begin{array}{l}\text { Net income per Mg of } \\
\text { rearing substrate (USD) }\end{array}$} \\
\hline & & & & & & & & 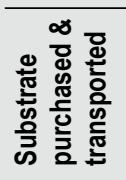 & 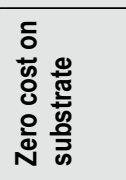 \\
\hline \multicolumn{10}{|c|}{ BSF farming for larvae production only } \\
\hline BSG & 89.3 & 45.3 & na & 40.7 & na & 40.7 & na & -214.1 & 13.4 \\
\hline \multicolumn{10}{|c|}{ BSF farming for larvae and frass fertiliser production } \\
\hline BSG & 86.7 & 45.3 & 472 & 40.7 & 141.7 & 182.5 & 77.6 & -79.9 & 147.6 \\
\hline BSG+9sawdust & 85.7 & 43.2 & 451 & 38.9 & 135.4 & 174.3 & 77.6 & -68.8 & 134.0 \\
\hline BSG+20sawdust & 84.3 & 37.4 & 696 & 33.6 & 208.8 & 242.4 & 86.1 & 22.4 & 195.9 \\
\hline BSG+32sawdust & 82.6 & 32.1 & 555 & 28.9 & 166.5 & 195.4 & 85.2 & -50.7 & 143.3 \\
\hline BSG+44sawdsut & 81.0 & 34.2 & 580 & 30.9 & 174.0 & 204.8 & 84.8 & 21.1 & 147.2 \\
\hline
\end{tabular}

${ }^{1}$ Costs of production: BSG $=0.0522$ USD $/ \mathrm{kg}$, sawdust $=0.02 \mathrm{USD} / \mathrm{kg}$, labour $=1.25$ USD $/$ hour. Sources of revenue: $\mathrm{BSF}$ larvae $=0.9$ USD $/ \mathrm{kg}$, frass fertiliser $=$ $0.3 \mathrm{USD} / \mathrm{kg}$.

${ }^{2}$ BSG = brewery spent grains, 9sawdsut, 20sawdust, 32sawdust and 44sawdust = amendment of brewery spent grain with sawdust at inclusion levels of 9,20 , 32 and $44 \%$ (weight/weight), respectively, na $=$ not applicable. 
Table 2. Economic returns from black soldier fly (BSF) production using biochar and gypsum amended rearing substrates. ${ }^{1,2}$

\begin{tabular}{|c|c|c|c|c|c|c|c|c|c|}
\hline \multirow[b]{2}{*}{ Rearing substrates } & \multirow{2}{*}{ 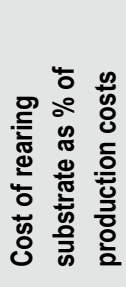 } & \multirow[b]{2}{*}{ 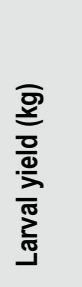 } & \multirow{2}{*}{ 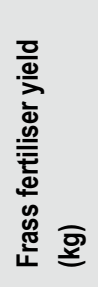 } & \multirow[b]{2}{*}{ 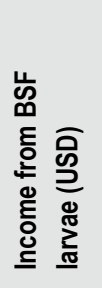 } & \multirow{2}{*}{ 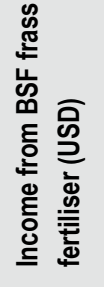 } & \multirow{2}{*}{ 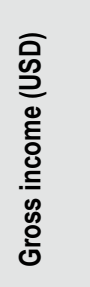 } & \multirow{2}{*}{ 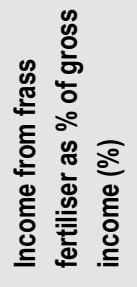 } & \multicolumn{2}{|c|}{$\begin{array}{l}\text { Net income per Mg of } \\
\text { rearing substrate (USD) }\end{array}$} \\
\hline & & & & & & & & 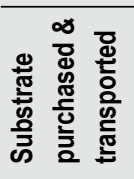 & 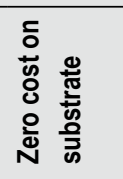 \\
\hline \multicolumn{10}{|c|}{ BSF farming for larvae production only } \\
\hline BSG & 89.6 & 34.6 & na & 31.1 & na & 31.1 & na & -232.6 & 37.9 \\
\hline \multicolumn{10}{|c|}{ BSF farming for larvae and frass fertiliser production } \\
\hline BSG & 87.2 & 34.6 & 585 & 31.1 & 175.4 & 206.5 & 84.9 & -64.7 & 171.7 \\
\hline BSG+5gypsum & 88.2 & 36.3 & 696 & 32.6 & 208.9 & 241.6 & 86.4 & -53.9 & 182.5 \\
\hline BSG+10gypsum & 89.1 & 31.7 & 802 & 28.6 & 240.6 & 269.2 & 89.3 & -50.6 & 185.6 \\
\hline BSG+15gypsum & 89.9 & 26.1 & 878 & 23.5 & 263.4 & 286.9 & 91.8 & -56.8 & 179.6 \\
\hline BSG+5bicohar & 87.9 & 41.4 & 633 & 37.3 & 190.0 & 227.2 & 83.6 & -60.5 & 175.9 \\
\hline BSG+10biochar & 88.5 & 53.6 & 696 & 48.3 & 208.9 & 257.2 & 81.2 & -47.1 & 189.3 \\
\hline BSG+15biochar & 89.1 & 63.4 & 759 & 57.1 & 227.7 & 284.8 & 80.0 & -36.0 & 200.4 \\
\hline BSG+20biochar & 89.7 & 64.9 & 876 & 58.4 & 262.8 & 321.1 & 81.8 & -16.1 & 220.3 \\
\hline
\end{tabular}

$20 \%$ sawdust (Table 1), 10\% gypsum, or $20 \%$ biochar (Table 2) was higher than income obtained using an unamended substrate, substrate amendment is recommended for higher profit margins. Thus, such innovations in BSF rearing have the potential for maximising profits from BSF farming and improving the sustainability of insect farming as a business (Van Huis, 2013).

\section{Economic gains of maize production using frass fertiliser}

Maize production using mineral fertiliser generated higher net maize income than the frass fertiliser and commercial organic (SAFI) fertilisers (Table 3). The findings are consistent with previous studies that reported higher net income in mineral fertiliser treated maize than organic fertilisers (Mucheru-Muna et al., 2014). This could be partly attributed to higher labour costs during manure application. The net maize income generated using 30 and $60 \mathrm{~kg} \mathrm{~N} /$ ha of frass fertiliser was higher than those achieved using equivalent commercial organic fertiliser rates by 29 and $44 \%$, respectively. A benefit-cost ratio (BCR) of 1.5 at $30 \mathrm{~kg} \mathrm{~N} /$ ha of frass fertiliser indicates the profitability of producing and utilising frass fertilisers (Table 3 ). The results suggest that it is less profitable to apply BSF frass fertiliser at higher than $30 \mathrm{~kg} \mathrm{~N} / \mathrm{ha}$.
Considering a farmer who produces their frass fertiliser and uses it for maize production, the net income would increase by 30,67 , and $232 \%$ for maize grown using 30,60 , and $100 \mathrm{~kg} \mathrm{~N} /$ ha, respectively, compared to purchasing the same frass fertiliser (Table 4). This production system also resulted in higher BCR, return on investment (ROI), and profit margins than growing maize using urea fertiliser compared to when BSF frass fertiliser is purchased. Our results are consistent with other researchers who established that proper utilisation of organic resources could boost crop productivity (Rusinamhodzi et al., 2013, 2016). Using homemade frass fertiliser would contribute to a circular economy concept, whereby the frass from BSF farming is converted into organic fertiliser for use in crop fields. Such innovative approaches can improve farm productivity through the sustainable use of available resources (Vanlauwe et al., 2014).

\section{Economically optimum frass fertiliser rate for maize production}

The lower optimum $\mathrm{N}$ rate achieved using frass fertiliser (79 kg N/ha) (Figure 3A-C) implies that one would incur less fertiliser expenses while using frass fertiliser for maize production compared to urea (100 kg N/ha) and commercial organic fertiliser (120 kg N/ha) where higher costs would 
Table 3. Economic returns from maize production if black soldier fly (BSF) frass fertiliser is bought at the same price as the commercial organic fertiliser. ${ }^{1,2}$

\begin{tabular}{lllllll} 
Fertiliser treatments & $\begin{array}{l}\text { Grain yield } \\
\text { (kg/ha) }\end{array}$ & $\begin{array}{l}\text { Gross income } \\
\text { (USD) }\end{array}$ & $\begin{array}{l}\text { Net income } \\
\text { (USD) }\end{array}$ & Benefit-cost ratio & $\begin{array}{l}\text { Return on investment } \\
\text { (\%) }\end{array}$ & $\begin{array}{l}\text { Gross margin } \\
\text { (\%) }\end{array}$ \\
30N FF & 5,077 & 2,038 & 1,233 & 1.5 & 153.3 & 60.3 \\
60N FF & 5,768 & 2,324 & 1,091 & 0.9 & 88.4 & 46.4 \\
100N FF & 5,937 & 2,417 & 548 & 0.3 & 29.3 & 22.3 \\
30N SAFI & 4,048 & 1,635 & 959 & 1.4 & 141.8 & 57.8 \\
60N SAFI & 4,242 & 1,733 & 757 & 0.8 & 77.5 & 42.8 \\
100N SAFI & 4,809 & 1,952 & 756 & 0.4 & 41.9 & 29.1 \\
30N UREA & 4,481 & 1,836 & 1,425 & 3.5 & 346.4 & 76.9 \\
60N UREA & 5,039 & 2,035 & 1,589 & 3.5 & 355.9 & 77.8 \\
100N UREA & 5,588 & 2,242 & 1,748 & 3.6 & 354.3 & 77.8 \\
\hline
\end{tabular}

${ }^{1}$ Cost of production: urea $=0.54 \mathrm{USD} / \mathrm{kg}, \mathrm{SAFI}=0.3 \mathrm{USD} / \mathrm{kg}$, maize seed $=1.8 \mathrm{USD} / \mathrm{kg}$, labour $=1.25 \mathrm{USD} / \mathrm{hour}$. Sources of revenue: maize grain $=0.37 \mathrm{USD} /$ $\mathrm{kg}$, maize stover $=0.0221 \mathrm{USD} / \mathrm{kg}$.

${ }^{2} 30 \mathrm{~N}, 60 \mathrm{~N}$ and $100 \mathrm{~N}=$ application rates equivalent to 30,60 and $100 \mathrm{~kg} \mathrm{~N} / \mathrm{ha}$, respectively, $\mathrm{FF}=$ frass fertiliser, $\mathrm{SAFI}=$ commercial organic fertiliser, urea $=$ commercial mineral $\mathrm{N}$ fertiliser, $\mathrm{N}=$ nitrogen

Table 4. Economic returns from maize production if black soldier fly (BSF) frass fertiliser is directly used on the farm. ${ }^{1}$

\begin{tabular}{lllll}
$\begin{array}{l}\text { Frass fertiliser rates } \\
\text { (kg N/ha) }\end{array}$ & $\begin{array}{l}\text { Net income } \\
\text { (USD) }\end{array}$ & Benefit-cost ratio & $\begin{array}{l}\text { Return on investment } \\
\text { (\%) }\end{array}$ & $\begin{array}{l}\text { Gross margin } \\
(\%)\end{array}$ \\
30 & 1,598 & 3.63 & 363 & 78.3 \\
60 & 1,819 & 3.61 & 361 & 78.1 \\
100 & 1,817 & 3.03 & 303 & 75.0 \\
\hline
\end{tabular}

${ }^{1}$ Production costs: labour $=1.25$ USD $/$ hour. Sources of revenue: maize grain $=0.37 \mathrm{USD} / \mathrm{kg}$, maize stover $=0.0221 \mathrm{USD} / \mathrm{kg}$.
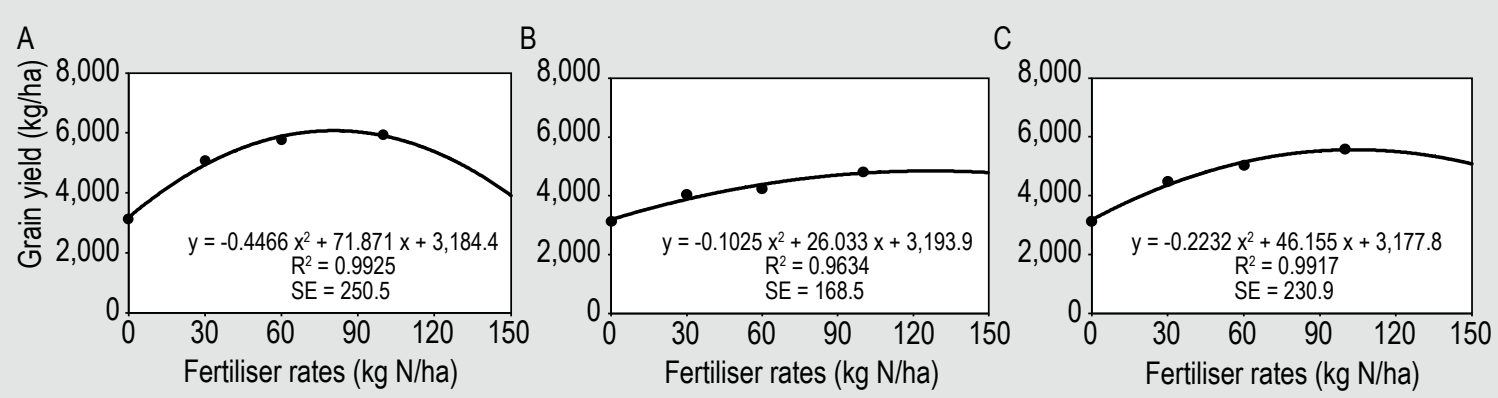

Figure 3. Yield response curves used to determine economically optimum rates of (A) frass fertiliser, (B) commercial organic fertiliser and $(C)$ urea. Note: in a perfect market, frass fertiliser should be sold at higher price because of its higher productivity. SE = standard error.

be incurred to purchase the higher quantities of fertilisers required. The results of optimum economic rates were higher than the rates which gave the highest net profits, returns on investment, and gross profit margins because the model used to determine optimum yields only considers the cost of fertiliser (Bachmaier and Gandorfer, 2012; Naher et al., 2011) and does not take into account the other costs of maize production such as labor.

The results of the stochastic dominance analysis (Figure 4) indicate that for all fertilisers, grain yield cumulative distribution with frass fertiliser is to the right of yield 


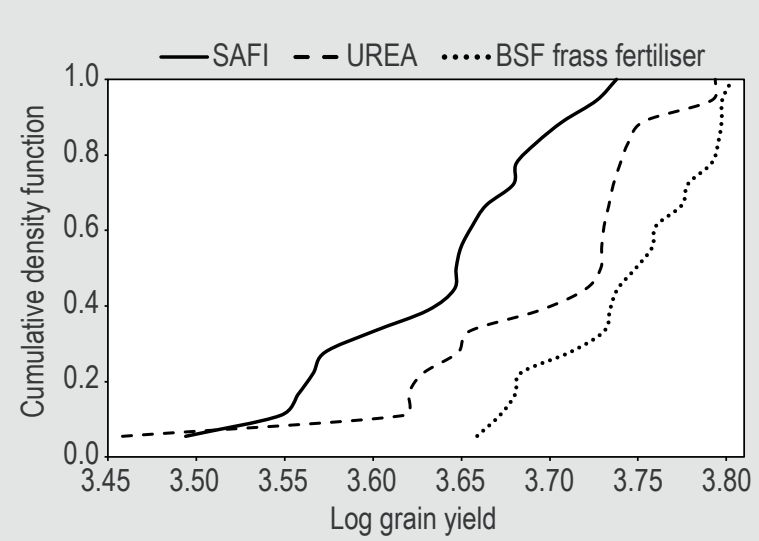

Figure 4. Stochastic dominance analysis of impact of black soldier fly (BSF) frass fertiliser on maize production. SAFI = commercial organic fertiliser, urea $=$ commercial mineral $\mathbf{N}$ fertiliser.

distributions of SAFI organic fertiliser and urea fertiliser, implying that yield with frass fertiliser holds first-order stochastic dominance over those from SAFI and urea treated plots. This, therefore, indicates that compared to SAFI and urea, the application of frass fertiliser produced higher maize grain yields. Therefore, frass fertiliser could be a complete or partial substitute to the scarce yet lowquality organic resources used in most sub-Saharan African countries (Ndambi et al., 2019).

The yield distribution from plots amended with urea fertiliser dominated yield distributions of SAFI, an indication that the use of urea fertiliser produces significantly (difference $=0.67 ; P=0.01$ ) higher grain yields than the commercial organic fertiliser as indicated by results of the two-sample Kolmogorov-Smirnov test. However, grain yield distributions from plots treated with BSF frass fertiliser and urea fertiliser did not vary significantly (difference $=$ $0.39 ; P=0.131$ ). Findings from the present study are crucial in reducing heavy reliance on expensive mineral fertilisers by adopting high-quality organic fertilisers such as BSF frass fertiliser.

\section{Conclusions}

This study provides the first report on the circular economy of BSF farming. It demonstrates that unless feedstock for rearing BSF is available on-farm, the profit margins might be limited due to purchase and transportation costs. The combination of insect-based frass organic fertiliser and animal feed provided higher economic benefits. This can improve smallholder farmers' food security and livelihoods. Findings showed that the utilisation of frass fertiliser for maize production would further attract higher profitability than existing commercial organic fertilisers. In addition to the direct economic benefits, social and environmental services of BSF framing will further increase the benefits of insect farming. Thus, scaling up insect-based feed and frass fertiliser sustainable and innovative technologies would require more research on quantifying the economic feasibility and social-environmental services of BSF farming across different production systems.

\section{Acknowledgements}

We are grateful for the financial support provided by the Canadian International Development Research Centre (IDRC) and the Australian Centre for International Agricultural Research (ACIAR) (INSFEED-Phase 2: Cultivate Grant No: 108866-001), Norwegian Agency for Development Cooperation, the Section for research, innovation, and higher education grant number RAF-3058 KEN-18/0005 (CAP-Africa), the Netherlands Organization for Scientific Research, WOTRO Science for Global Development (NWO-WOTRO) (ILIPA-W 08.250.202), and The Rockefeller Foundation (SiPFeed-2018 FOD 009) through the International Centre of Insect Physiology and Ecology (icipe). We also gratefully acknowledge the support of the icipe core funders such as the United Kingdom's Foreign, Commonwealth \& Development Office (FCDO); the Swedish International Development Cooperation Agency (Sida); the Swiss Agency for Development and Cooperation (SDC); the Federal Democratic Republic of Ethiopia; and the Government of the Republic of Kenya. The views expressed herein do not necessarily reflect the official opinion of the donors. The first author, Dennis Beesigamukama, was financially supported by the German Academic Exchange Service (DAAD) In-Region Postgraduate Scholarship. The authors would like to thank Faith N. Wamurango, Shem Ondiaka, Joshua Wambua, Isiah E. Rachami, Kennedy K. Kiprotich, and Mathew K. Theuri for providing technical support during data collection.

\section{Conflict of interest}

The authors declare no conflict of interest.

\section{References}

Abro, Z., Kassie, M., Tanga, C., Beesigamukama, D. and Diiro, G., 2020. Socio-economic and environmental implications of replacing conventional poultry feed with insect-based feed in Kenya. Journal of Cleaner Production 265: 121871. https://doi.org/10.1016/j. jclepro.2020.121871

Africa Fertilizer, 2019. National fertilizer prices. Available at: https:// africafertilizer.org/national/ \#tab-id-3

Alltech, 2016. Global feed survey. Alltech, Lexington, KY, USA. Available at: http://stories.alltech.com/global-feed-survey-2016.html Anyega, A.O., Korir, N.K., Beesigamukama, D., Changeh, G.J., Nkoba, K., Subramanian, S., Van Loon, J.J.A., Dicke, M., 2021. Black soldier fly-composted organic fertilizer enhances growth, 
yield, and nutrient quality of three key vegetable crops in subSaharan Africa. Frontiers in Plant Science 12: 680312. https://doi. org/10.3389/fpls.2021.680312

Bachmaier, M. and Gandorfer, M., 2012. Estimating uncertainty of economically optimum $\mathrm{N}$ fertilizer rates. International Journal of Agronomy 2012, Article ID: 580294. https://doi. org/10.1155/2012/580294

Beesigamukama, D., Mochoge, B., Korir, N.K., Fiaboe, K.K.M., Nakimbugwe, D., Khamis, F.M., Subramanian, S. and Tanga, C.M., 2020a. Exploring black soldier fly frass as novel fertilizer for improved growth, yield, and nitrogen use efficiency of maize under field conditions. Frontiers in Plant Science 11: 574592. https://doi. org/10.3389/fpls.2020.574592

Beesigamukama, D., Mochoge, B., Korir, N., Musyoka, M.W., Fiaboe, K.K.M., Nakimbugwe, D., Khamis, F.M., Subramanian, S., Dubois, T., Ekesi, S. and Tanga, C.M., 2020b. Nitrogen fertilizer equivalence of black soldier fly frass fertilizer and synchrony of nitrogen mineralization for maize production. Agronomy 10: 1395. https:// doi.org/10.3390/agronomy10091395

Beesigamukama, D., Mochoge, B., Korir, N.K., Fiaboe, K.K.M., Nakimbugwe, D., Khamis, F.M., Dubois, T., Subramanian, S., Wangu, M.M., Ekesi, S. and Tanga, C.M., 2020c. Biochar and gypsum amendment of agro-industrial waste for enhanced black soldier fly larval biomass and quality frass fertilizer. PLoS ONE 15: e0238154. https://doi.org/10.1371/journal.pone.0238154

Beesigamukama, D., Mochoge, B., Korir, N.K., Fiaboe, K.K.M., Nakimbugwe, D., Khamis, F.M., Subramanian, S., Wangu, M.M., Dubois, T., Ekesi, S. and Tanga, C.M., 2021. Low-cost technology for recycling agro-industrial waste into nutrient-rich organic fertilizer using black soldier fly. Waste Management 119: 183-194. https:// doi.org/10.1016/j.wasman.2020.09.043

Bortolini, S., Macavei, L.I., Hadj Saadoun, J., Foca, G., Ulrici, A., Bernini, F., Malferrari, D., Setti, L., Ronga, D. and Maistrello, L., 2020. Hermetia illucens (L.) larvae as chicken manure management tool for circular economy. Journal of Cleaner Production 262: 121289. https://doi.org/10.1016/j.jclepro.2020.121289.

Chia, S.Y., Tanga, C.M., Osuga, I.M., Alaru, A.O., Mwangi, D.M., Githinji, M., Subramanian, S., Fiaboe, K.K.M., Ekesi, S., Van Loon, J.J.A. and Dicke, M., 2019. Effect of dietary replacement of fishmeal by insect meal on growth performance, blood profiles and economics of growing pigs in Kenya. Animals 9: 705. https://doi. org/10.3390/ani9100705

Chia, S.Y., Tanga, C.M., Osuga, I.M., Mohamed, S.A., Khamis, F.M., Salifu, D., Sevgan, S., Fiaboe, K.K.M., Niassy, S., Van Loon, J.J.A., Dicke, M. and Ekesi, S., 2018. Effects of waste stream combinations from brewing industry on performance of black soldier fly, Hermetia illucens (Diptera: Stratiomyidae). PeerJ 6: e5885. https://doi. org/10.7717/peerj.5885

Choi, S. and Hassanzadeh, N., 2019. BSFL frass: a novel biofertilizer for improving plant health while minimizing environmental impact. The Candian Science Fair Journal 2: 41-46. https://doi.org/10.18192/ csfj.v2i220194146

Cobo, J.G., Dercon, G. and Cadisch, G., 2010. Nutrient balances in African land use systems across different spatial scales: a review of approaches, challenges and progress. Agriculture Ecosystems and Environment 136: 1-15. https://doi.org/10.1016/j.agee.2009.11.006
Dobermann, D., Swift, J.A. and Field, L.M., 2017. Opportunities and hurdles of edible insects for food and feed. Nutrition Bulletin 42: 293-308. https://doi.org/10.1111/nbu.12291

Food and Agriculture Organisation (FAO), 2017. The state of food and agriculture. Leveraging food systems for inclusive rural transformation. FAO, Rome, Italy. https://doi.org/10.2307/2938399

Gärttling, D., Kirchner, S.M. and Schulz, H., 2020. Assessment of the nand p-fertilization effect of black soldier fly (Diptera: Stratiomyidae) by-products on maize. Journal of Insect Science 20(5). https://doi. org/10.1093/jisesa/ieaa089

Huang, G.F., Wong, J.W.C., Wu, Q.T. and Nagar, B.B., 2004. Effect of $\mathrm{C} / \mathrm{N}$ on composting of pig manure with sawdust. Waste Management 24: 805-813. https://doi.org/10.1016/j.wasman.2004.03.011

Humanitarian Data Exchange, 2020. Kenya maize prices 2019. Available at: https://data.humdata.org/dataset/wfp-food-prices-for-kenya

Kenya Government, 2019. The regulation of wages. General amendment order 2018. Kenya Government, Nairobi, Kenya.

Kierończyk, B., Sypniewski, J., Rawski, M., Czekała, W., Świątkiewicz, S. and Józefiak, D., 2020. From waste to sustainable feed material: the effect of Hermetia illucens oil on the growth performance, nutrient digestibility, and gastrointestinal tract morphometry of broiler chickens. Annals of Animal Science 20: 157-177. https:// doi: 10.2478/aoas-2019-0066

Kihara, J., Nziguheba, G., Zingore, S., Coulibaly, A., Esilaba, A., Kabambe, V., Njoroge, S., Palm, C. and Huising, J., 2016. Understanding variability in crop response to fertilizer and amendments in sub-Saharan Africa. Agriculture Ecosystems and Environment 229: 1-12. https://doi.org/10.1016/j.agee.2016.05.012 Kroeckel, S., Harjes, A.G.E., Roth, I., Katz, H., Wuertz, S., Susenbeth, A. and Schulz, C., 2012. When a turbot catches a fly: evaluation of a pre-pupae meal of the black soldier fly (Hermetia illucens) as fish meal substitute - growth performance and chitin degradation in juvenile turbot (Psetta maxima). Aquaculture 364-365: 345-352. https://doi.org/10.1016/j.aquaculture.2012.08.041

Lalander, C.H., Fidjeland, J., Diener, S., Eriksson, S. and Vinnerås, B., 2015. High waste-to-biomass conversion and efficient Salmonella spp. reduction using black soldier fly for waste recycling. Agronomy for Sustainable Development 35: 261-271. https://doi.org/10.1007/ s13593-014-0235-4

Li, Y., Luo, W., Li, G., Wang, K. and Gong, X., 2018. Performance of phosphogypsum and calcium magnesium phosphate fertilizer for nitrogen conservation in pig manure composting. Bioresource Technology 250: 53-59. https://doi.org/10.1016/j. biortech.2017.07.172

Liverpool-Tasie, L.S.O., Omonona, B.T., Sanou, A. and Ogunleye, W.O., 2017. Is increasing inorganic fertilizer use for maize production in SSA a profitable proposition? Evidence from Nigeria. Food Policy 67: 41-51. https://doi.org/10.1016/j.foodpol.2016.09.011

Magalhães, R., Sánchez-López, A., Leal, R.S., Martínez-Llorens, S., Oliva-Teles, A. and Peres, H., 2017. Black soldier fly (Hermetia illucens) pre-pupae meal as a fish meal replacement in diets for European seabass (Dicentrarchus labrax). Aquaculture 476: 79-85. https://doi.org/10.1016/j.aquaculture.2017.04.021

Makkar, H.P.S., Tran, G., Heuzé, V. and Ankers, P., 2014. Stateof-the-art on use of insects as animal feed. Animal Feed Science and Technology 197: 1-33. https://doi.org/10.1016/j. anifeedsci.2014.07.008 
Mertenat, A., Diener, S. and Zurbrügg, C., 2019. Black soldier fly biowaste treatment - assessment of global warming potential. Waste Management 84: 173-181. https://doi.org/10.1016/j. wasman.2018.11.040

Mucheru-Muna, M., Mugendi, D., Pypers, P., Mugwe, J., Kung’U, J., Vanlauwe, B. and Merckx, R., 2014. Enhancing maize productivity and profitability using organic inputs and mineral fertilizer in central Kenya small-hold farms. Experimental Agriculture 50: 250-269. https://doi.org/10.1017/S0014479713000525

Naher, U.A., Saleque, M.A., Panhwar, Q.A., Radziah, O. and Jusop, S., 2011. Techniques of efficient fertilizer management for wetland rice - a review. Australian Journal of Crop Science 5: 1661-1669.

Ndambi, O.A., Pelster, D.E., Owino, J.O., De Buisonjé, F. and Vellinga, T., 2019. Manure management practices and policies in sub-Saharan Africa: implications on manure quality as a fertilizer. Frontiers in Sustainable Food Systems 3: 29. https://doi.org/10.3389/ fsufs.2019.00029

Oonincx, D.G.A.B., Van Huis, A. and Van Loon, J.J.A., 2015. Nutrient utilisation by black soldier flies fed with chicken, pig, or cow manure. Journal of Insects as Food and Feed 1: 131-139. https:// doi.org/10.3920/JIFF2014.0023

Quilliam, R.S., Nuku-Adeku, C., Maquart, P., Little, D., Newton, R. and Murray, F., 2020. Integrating insect frass biofertilisers into sustainable peri-urban agro-food systems. Journal of Insects as Food and Feed 6: 315-322. https://doi.org/10.3920/jiff2019.0049

Rufino, M.C., Dury, J., Tittonell, P., Van Wijk, M.T., Herrero, M., Zingore, S., Mapfumo, P. and Giller, K.E., 2011. Competing use of organic resources, village-level interactions between farm types and climate variability in a communal area of NE Zimbabwe. Agricultural Systems 104: 175-190. https://doi.org/10.1016/j.agsy.2010.06.001

Rusinamhodzi, L., Corbeels, M., Zingore, S., Nyamangara, J. and Giller, K.E., 2013. Pushing the envelope? Maize production intensification and the role of cattle manure in recovery of degraded soils in smallholder farming areas of Zimbabwe. Field Crops Research 147: 40-53. https://doi.org/10.1016/j.fcr.2013.03.014

Rusinamhodzi, L., Dahlin, S. and Corbeels, M., 2016. Living within their means: reallocation of farm resources can help smallholder farmers improve crop yields and soil fertility. Agriculture, Ecosystems and Environment 216: 125-136. https://doi.org/10.1016/j. agee.2015.09.033

Sanchez-Monedero, M.A., Cayuela, M.L., Roig, A., Jindo, K., Mondini, C. and Bolan, N., 2018. Role of biochar as an additive in organic waste composting. Bioresource Technology 247: 1155-1164. https:// doi.org/10.1016/j.biortech.2017.09.193

Ssepuuya, G., Namulawa, V., Mbabazi, D., Mugerwa, S., Fuuna, P., Nampijja, Z., Ekesi, S., Fiaboe, K.K.M. and Nakimbugwe, D., 2017. Use of insects for fish and poultry compound feed in sub-Saharan Africa - a systematic review. Journal of Insects as Food and Feed 3: 289-302. https://doi.org/10.3920/JIFF2017.0007

Schiavone, A., Cullere, M., De Marco, M., Meneguz, M., Biasato, I., Bergagna, S., Dezzutto, D., Gai, F., Dabbou, S., Gasco, L. and Zotte, A.D., 2017. Partial or total replacement of soybean oil by black soldier fly larvae (Hermetia illucens L.) fat in broiler diets: effect on growth performances, feed-choice, blood traits, carcass characteristics and meat quality. Italian Journal of Animal Science 16: 93-100. https://doi.org/10.1080/1828051X.2016.1249968
Setti, L., Francia, E., Pulvirenti, A., Gigliano, S., Zaccardelli, M., Pane, C., Caradonia, F., Bortolini, S., Maistrello, L. and Ronga, D., 2019. Use of black soldier fly (Hermetia illucens (L.), Diptera: Stratiomyidae) larvae processing residue in peat-based growing media. Waste Management 95: 278-288. https://doi.org/10.1016/j. wasman.2019.06.017

Shumo, M., Osuga, I.M., Khamis, F.M., Tanga, C.M., Fiaboe, K.K.M., Subramanian, S., Ekesi, S., Van Huis, A. and Borgemeister, C., 2019. The nutritive value of black soldier fly larvae reared on common organic waste streams in Kenya. Scientific Reports 9: 10110. https:// doi.org/10.1038/s41598-019-4.6603-z

Stewart, Z.P., Pierzynski, G.M., Middendorf, B.J. and Vara Prasad, P.V., 2020. Approaches to improve soil fertility in sub-Saharan Africa. Journal of Experimental Botany 71: 632-641. https://doi. org/10.1093/jxb/erz446

Sypniewski, J., Kierończyk, B., Benzertiha, A., Mikołajczak, Z., Pruszyńska-Oszmałek, E., Kołodziejski, P., Sassek, M., Rawski M., Czekała, W. and Józefiak, D., 2020. Replacement of soybean oil by Hermetia illucens fat in turkey nutrition: effect on performance, digestibility, microbial community, immune and physiological status and final product quality. British Poultry Science 61: 294-302. https://doi: 10.1080/00071668.2020.1716302

Tittonell, P., Corbeels, M., Van Wijk, M.T., Vanlauwe, B. and Giller, K.E., 2008. Combining organic and mineral fertilizers for integrated soil fertility management in smallholder farming systems of Kenya: explorations using the crop-soil model FIELD. Agronomy Journal 100: 1511-1526. https://doi.org/10.2134/agronj2007.0355

Tully, K., Sullivan, C., Weil, R. and Sanchez, P., 2015. The state of soil segradation in sub-Saharan Africa: baselines, trajectories, and solutions. Sustainability 7: 6523-6552. https://doi.org/10.3390/ su7066523

Van Huis, A., 2013. Potential of insects as food and feed in assuring food security. Annual Review of Entomology 58: 563-583. https:// doi.org/10.1146/annurev-ento-120811-153704

Van Huis, A. and Oonincx, D.G.A.B., 2017. The environmental sustainability of insects as food and feed. A review. Agronomy for Sustainable Development 37: 43. https://doi.org/10.1007/s13593017-0452-8

Vanlauwe, B., Coyne, D., Gockowski, J., Hauser, S., Huising, J., Masso, C., Nziguheba, G., Schut, M. and Van Asten, P., 2014. Sustainable intensification and the African smallholder farmer. Current Opinion in Environmental Sustainability 8: 15-22. https://doi.org/10.1016/j. cosust.2014.06.001

Vanlauwe, B., Descheemaeker, K., Giller, K.E., Huising, J., Merckx, R., Nziguheba, G. and Wendt, J., 2015. Integrated soil fertility management in sub-Saharan Africa: unravelling local adaptation. Soil Journal 1: 491-508. https://doi.org/10.5194/soil-1-491-2015

Wortmann, C.S., Kaizzi, K.C., Maman, N., Cyamweshi, A., Dicko, M., Garba, M., Milner, M., Senkoro, C., Tarfa, B., Tettah, F., Kibunja, C., Munthali, M., Nalivata, P., Nkonde, D., Nabahungu, L., Ouattara, K. and Serme, I., 2019. Diagnosis of crop secondary and micronutrient deficiencies in sub-Saharan Africa. Nutrient Cycling in Agroecosystems 113: 127-140. https://doi.org/10.1007/s10705018-09968-7 